\title{
Antibacterial potential of Actinobacteria from a Limestone Mining Site in Meghalaya, India
}

\author{
Debulman Syiemiong ${ }^{1,2}$ (D) and Dhruva Kumar Jha ${ }^{1 *}$ (iD \\ ${ }^{1}$ Microbial Ecology Laboratory, Department of Botany, Gauhati University, Guwahati - 781 014, India. ${ }^{2}$ Department \\ of Botany, St. Edmund's College, Shillong - 793 003, India.
}

\begin{abstract}
This work attempts to assess the antimicrobial potential of actinobacteria isolated from limestone mining sites which hitherto, is an under-explored niche for exploring novel bioactive metabolites. Actinobacteria were selectively isolated from Mawsmai, Meghalaya, India, a limestone mining area, using different pretreatment methods. Forty-seven isolates were obtained, which were identified based on their morphological, biochemical and chemotaxonomical characteristics. Streptomyces was the dominant cultivable genera which constituted $76 \%$ of the isolates cultivated. All the isolates were screened for antimicrobial activity against three Gram-negative viz. Escherichia coli, Pseudomonas aeruginosa and Klebsiella pneumoniae, and three Gram-positive bacteria viz. Staphylococcus aureus, Bacillus subtilis and Micrococcus luteus and besides, two candidal species viz. Candida albicans and C. tropicalis. $19 \%$ of the total isolates showed antibacterial activity against at least one of the test bacterial strains used. The identity of the four bioactive isolates viz. LD-21, LD-29, LD-34 and LD-39 was confirmed as Streptomyces sp. on the basis of their 16S rDNA sequence and 16S rRNA secondary structure analysis. These isolates showed antibacterial activity against at least two Gram-positive bacteria and all the four harbored at least one of the three biosynthetic gene clusters viz. type-I and type-II polyketide synthases and non-ribosomal peptide synthetase which are related to synthesis of bioactive metabolites.

Keywords: Streptomyces, Antimicrobial, Biosynthetic gene clusters, 16S rRNA secondary structure.
\end{abstract}

\footnotetext{
*Correspondence: dkjhabot07@gmail.com; +91-9435047422
}

(Received: 01 May 2019; accepted: 10 June 2019)

Citation: Debulman Syiemiong and Dhruva Kumar Jha, Antibacterial potential of Actinobacteria from a Limestone Mining Site in Meghalaya, India, J Pure Appl Microbiol., 2019; 13(2): 789-802. doi: 10.22207/JPAM.13.2.14

(c) The Author(s) 2019. Open Access. This article is distributed under the terms of the Creative Commons Attribution 4.0 International License which permits unrestricted use, sharing, distribution, and reproduction in any medium, provided you give appropriate credit to the original author(s) and the source, provide a link to the Creative Commons license, and indicate if changes were made. 


\section{INTRODUCTION}

Actinobacteria is a phylum of Grampositive or Gram-variable bacteria with diverse morphology ranging from cocci to highly differentiated mycelia ${ }^{1}$. They have high $\mathrm{G}+\mathrm{C}$ content in their DNA ranging from $50-70 \mathrm{~mol}$ $\%{ }^{1}$. They are widely distributed in all kinds of terrestrial and aquatic environments ${ }^{1}$. Most of them are saprophytic, however, some are pathogenic to plants and animals ${ }^{1}$. Actinobacteria has been one of the important sources of naturallyderived antibiotics for the last 75 years and will remain so in the years to come especially for the discovery of novel antibiotics ${ }^{2}$. Antibiotics have also been discovered from various other natural sources like plants, animals, fungi and bacteria ${ }^{3}$. Naturally-derived antibiotics, even though are more difficult to discover due to complexity in identifying new scaffolds ${ }^{4}$, are superior over the synthetic ones because they are products of natural selection and have gone through the long process of evolution and have established compatibility with biological targets ${ }^{4}$. More than two-thirds of clinically used antibiotics were either natural products or their semi-synthetic derivatives ${ }^{5}$. However, in recent years, there has been some lag in discovering new classes of natural product antibiotics and this has put a pressure on the pharmaceutical industry due to the emergence of resistance amongst the pathogens. Reasons like rediscovery of known compounds, complexity of the natural antibiotic scaffolds and their suitability as drugs, their unstability, very low yield and difficulty in purification have constrained pharmaceutical companies to shift their interests to synthetic antibiotics in the $21^{\text {st }}$ century ${ }^{4}$ to stay ahead of emerging antibioticresistance. Recent advancement in new generation genome sequencing technology, bioinformatics, analytical chemistry, metagenomics and genomescale metabolic models ${ }^{4-7}$ has now impelled the researchers to return to natural products for drug discovery. Search for microbial taxa from underexplored ecological niches increases the possibility of discovering novel molecules from nature ${ }^{5}$. Limestone-rich areas mainly dominated by a $\mathrm{CaCO}_{3}$ environment, are under-explored ecological niches for mining of microorganisms for various metabolic properties. Recent studies have revealed that both hypogean and epigean limestone actinobacteria are potential antibiotics producers ${ }^{8-14}$. The state of Meghalaya located in the north-eastern part of India falls under the Indo-Burma Biodiversity Hotspot $^{15}$. Therefore, mining for antibiotics producing actinobacteria from under-explored ecological niche of limestone mines of diversityrich state of Meghalaya enhances the possibility of discovery of novel metabolites. This paper, therefore, reports on diversity of actinobacteria having antibacterial activities from limestone mining areas located at Mawsmai, Meghalaya, India.

\section{MATERIALS AND METHODS Sample collection}

The sampling site was from a limestone mining area at Mawsmai near Sohra in Meghalaya, India (N25 $\left.15.364^{\prime} \mathrm{E}^{\circ} 1^{\circ} 43.885^{\prime}\right)$. Soil samples from around the mining area were aseptically collected in sterilized polythene bags and brought to the lab and stored at $4 \pm 1^{\circ} \mathrm{C}$ until further use.

\section{Determination of soil physico-chemical characteristics}

Soil and air temperatures (in ${ }^{\circ} \mathrm{C}$ ) were measured in three different locations using a soil thermometer and an ordinary thermometer respectively. Moisture content (\%) of the soil was determined gravimetrically ${ }^{16}$. $\mathrm{pH}$ was determined using a digital $\mathrm{pH}$ meter ${ }^{17}$. Organic carbon was determined following the method of Anderson and Ingram (1993) ${ }^{17}$. Total nitrogen was determined by the Kjeldahl Method ${ }^{18}$. Available Phosphorus was determined by the molybdate blue method ${ }^{16}$. Potassium was determined by the flame photometer method ${ }^{18}$.

Soil pretreatment and isolation of actinobacteria The collected soil samples were air-dried at room temperature for one week and mixed equally into one composite sample. The air-dried samples were then pretreated by (i) dry heating at $120^{\circ} \mathrm{C}$ for 1 hour, (ii) wet heating at $70^{\circ} \mathrm{C}$ for 15 minutes in a water bath, (iii) $1.5 \%$ phenol at $25 \pm 1^{\circ} \mathrm{C}$ for 30 minutes, (iv) $0.2 \%$ humic acid at $25 \pm 1^{\circ} \mathrm{C}$ for 30 minutes and $(v)$ combination of $i$ \& iii. The unpretreated air-dried soil samples were also used as inoculum for isolation. $1 \mathrm{~g}$ pretreated and unpretreated soil samples were suspended in $9 \mathrm{ml}$ sterilized distilled water and serially diluted. All the undiluted and serially diluted soil sample suspensions were used as inocula for isolation. 
Five selective media were used for isolation viz. Actinomycete Isolation Agar (AIA), Bennett's Agar (BA), Starch Casein Agar (SCA), Streptomyces Agar (SA) and Humic acid Vitamin Agar (HVA) ${ }^{19}$. The above media were amended with Nystatin $(50 \mu \mathrm{g}$ $\left.\mathrm{ml}^{-1}\right)$ and Rifampicin $\left(20 \mu \mathrm{g} \mathrm{ml}^{-1}\right) .100 \mu \mathrm{l}$ of the soil sample suspensions were inoculated on the above selective media and incubated at $28 \pm 1^{\circ} \mathrm{C}$ for up to four weeks. Based on colony morphology, colonies were picked from the culture plates, sub-cultured and maintained in Bennett's agar medium. The recovery of actinobacterial colonies from different pretreated samples and media were recorded as actinobacterial population number in $\mathrm{cfu} \mathrm{g}^{-1}$ soil. All observations were recorded in triplicates and expressed as sample mean \pm standard error. Multiple comparisons of sample means were done using ANOVA with Duncan's test at $p \leq 0.05$. Statistical analysis was performed with XLSTAT software.

\section{Morphological characterization}

The selected colonies were grown in ISP3 (oat meal agar) medium by coverslip culture method ${ }^{20}$ and incubated at $28 \pm 1^{\circ} \mathrm{C}$ for 7 days. The coverslip cultures were then placed on a glass slide and observed under the microscope (Olympus CX21i) at 400X magnification for presence of aerial and substrate mycelia, spore chains and other reproductive structures.

Biochemical and chemotaxonomic characterization

Biochemical tests viz., casein, xanthine, hypoxanthine and tyrosine hydrolysis were performed following the methods of Berd $(1973)^{21}$. Chemotaxonomic analyses viz. cell wall chemotype of 2,6-diaminopimelic acid (DAP) and whole cell sugars were performed by thinlayer chromatography following the methods of Hasegawa et al. (1983)22. The scheme for preliminary identification of actinobacteria was followed according to Berd (1973) $)^{21}$ and Staneck and Roberts (1974) ${ }^{23}$.

\section{Phylogenetic analysis of 16S rDNA sequence}

Genomic DNA of the selected bioactive isolates were extracted by enzymatic method ${ }^{24}$ followed by PCR of $16 \mathrm{~S}$ rDNA. The primers used for amplification were 27F (5'-AGAGTTTGATCMTGGCTCAG-3') and A3R (5' -CCAGCCCCACCTTCGAC- $\left.3^{\prime}\right)^{25}$. PCR reactions were carried out in an $\mathrm{Eco96}^{\mathrm{TM}}$ thermal cycler (Himedia, India) in
$25 \mu \mathrm{l}$ reaction mixture containing $\mathrm{PCR}$ buffer (Promega) with $1.5 \mathrm{mM} \mathrm{MgCl}, 0.2 \mathrm{mM}$ of each dNTP (Promega), $0.5 \mu \mathrm{M}$ of each primer (IDT), $0.625 \mathrm{U}$ of Taq DNA polymerase (Promega) and $5 \mu \mathrm{l}$ of extracted DNA as template DNA. Amplification parameter was an initial denaturation of $95^{\circ} \mathrm{C}$ for 5 minutes, 35 cycles of $95^{\circ} \mathrm{C}$ for 45 seconds, $56^{\circ} \mathrm{C}$ for 60 seconds, $72^{\circ} \mathrm{C}$ for 90 seconds and final extension of $72^{\circ} \mathrm{C}$ for 7 minutes. The amplified products were analyzed by agarose gel electrophoresis (with $1.2 \% \mathrm{w} / \mathrm{v}$ agarose added with $1 \mu \mathrm{l} / 10 \mathrm{ml} \mathrm{v} / \mathrm{v}$ LabSafe $^{\mathrm{TM}}$ Nucleic Acid Stain, G-Biosciences). A 100bp DNA ladder was used for size reference. The amplified products were purified and sequenced at Xcelris Labs Ltd., Ahmedabad, India. The partial 16S rDNA sequences obtained were matched with type strains from EzBioCloud database ${ }^{26}$ for determining sequence similarities. Phylogenetic relationships of the selected bioactive isolates along with thirty-two related type strains were determined using MEGA version $7^{27}$ and phylogenetic tree was constructed using the Maximum Likelihood method based on the Tamura 3-parameter model ${ }^{28}$. A discrete Gamma distribution was used to model evolutionary rate differences among sites $(+G)$. The rate variation model allowed for some sites to be evolutionarily invariable (+I). Bootstrap analysis ${ }^{29}$ was done with 1000 replicates. The partial 16S rDNA sequences were deposited in GenBank.

\section{Phylogenetic analysis of predicted 16S rRNA} secondary structure

The use of 16S rRNA secondary structures for phylogenetic analysis of actinobacteria was understood from Ghosh et al. (2019) $)^{30}$. The 16S rDNA sequences obtained were converted into 16S rRNA sequences and subsequently the 16S rRNA secondary structures with their minimum free energy (MFE) were predicted using the RNAfold server ${ }^{31}$ at the ViennaRNA Web Services (http://rna.tbi.univie.ac.at/). The obtained 16S rRNA secondary structures of the selected bioactive isolates along with their MFEs were then compared with the related type strains from EzBioCloud database (which were used for phylogenetic analysis based on 16S rDNA sequence) to confirm their identity. Consensus $16 \mathrm{~S}$ rRNA secondary structures were also generated using the RNAalifold server ${ }^{32}$ at the ViennaRNA Web Services between the bioactive isolates and 
the related type strains with the closest MFEs to analyze for conserved regions. The selected 16SrDNA sequences with the closest MFEs were aligned using ClustalX 2.1 (http://www.clustal.org/ download/2.1/) and sequence overhangs trimmed before using the aligned file for generating consensus $16 \mathrm{~S}$ rRNA secondary structure.

Screening of isolates for antimicrobial activity Isolates were screened for antimicrobial activity against Escherichia coli MTCC 1669, Pseudomonas aeruginosa MTCC 4673, Klebsiella pneumoniae MTCC 10309, Staphylococcus aureus MTCC 9886, Bacillus subtilis MTCC 1305, Micrococcus luteus MTCC 1538, Candida albicans MTCC 7253 and C. tropicalis MTCC 184 . The above test microorganisms were obtained from Microbial Type Culture Collection and Gene Bank, CSIRInstitute of Microbial Technology, Chandigarh, India. Culture filtrates used for antimicrobial assays were prepared by first culturing the isolates in $5 \mathrm{ml}$ Bennett's broth supplemented with $0.05 \%$ humic acid, $\mathrm{pH} 7.5^{33}$ in $15 \mathrm{ml}$ tubes and incubated at $28 \pm 2^{\circ} \mathrm{C}$ for 15 days. The broth cultures were then filtered using an ordinary filter paper followed by sterilization using membrane filters (PVDF $0.2 \mu \mathrm{m}$ ). Uninoculated media were used as negativecontrols while amikacin $(30 \mu \mathrm{g})$, vancomycin $(30 \mu \mathrm{g})$ and amphotericin-B $(20 \mu \mathrm{g})$ discs were used as positive-controls. Antimicrobial screening was performed by agar-well diffusion method ${ }^{34}$. Antimicrobial activity was assessed as zone of inhibition $(\mathrm{mm})$ by subtracting the diameter of the agar-well from the diameter of inhibition. All the culture filtrates were prepared and tested in triplicates.

\section{Detection of biosynthetic gene clusters}

PCR was performed on the genomic DNA of the selected bioactive isolates for checking the presence of three biosynthetic gene clusters (BGCs) related to synthesis of bioactive metabolites viz. type I polyketide synthase (PKS-I), type II polyketide synthase (PKS-II) and Non-ribosomal peptide synthetase (NRPS) ${ }^{8,35}$. Three pairs of primers viz. K1F (5'-TSAAGTCSAACATCGGBCA-3') - M6R (5'-CGCAGGTTSCSGTACCAGTA-3'), KS $\alpha F$ (5'-TSGCSTGCTTGGAYGCSATC-3') - KS $\alpha R$ (5'-TGGAANCCGCCGAABCCGCT-3') and A3F (5'-GCSTACSYSATSTACACSTCSGG-3') - A7R (5'-SASGTCVCCSGTSCGGTAS- ${ }^{\prime}$ ) were used respectively ${ }^{8}$. PCR was performed in final volume of $25 \mu \mathrm{l}$ containing PCR buffer (Promega) with $1.5 \mathrm{mM} \mathrm{MgCl}, 0.2 \mathrm{mM}$ each dNTP (Promega), $0.4 \mu \mathrm{M}$ of each primer (IDT), $0.5 \mathrm{U}$ of Taq DNA polymerase (Promega), 10\% DMSO and $5 \mu$ of extracted DNA as template DNA. Multiplex PCR for PKS-I and PKS-II and simple PCR for NRPS were performed and amplifications were carried out in an $\mathrm{Eco96}^{\mathrm{TM}}$ thermal cycler (Himedia, India) in the following cycling parameter: initial denaturation of $95^{\circ} \mathrm{C}$ for 5 mins, 35 cycles of $95^{\circ} \mathrm{C}$ for 30 secs, $55^{\circ} \mathrm{C}$ (for PKS-I and PKS-II) $/ 57^{\circ} \mathrm{C}$ (for NRPS) for 2 mins, $72^{\circ} \mathrm{C}$ for 4 mins and final extension of $72^{\circ} \mathrm{C}$ for 10 mins.

\section{RESULTS AND DISCUSSION}

\section{Soil physico-chemical characteristics}

Soil and air temperatures of the study site at the time of sample collection (July) were $21^{\circ} \mathrm{C}$ and $19^{\circ} \mathrm{C}$ respectively akin to a sub-tropical climate as Mawsmai, Meghalaya, India falls under such climatic zone ${ }^{36}$. Moisture content of the soil was $16.64 \pm 3.85 \%$. The average soil $\mathrm{pH}$ was slightly alkaline $(7.12 \pm 0.9)$. Soil organic carbon was $2.46 \pm 0.05 \%$. Total soil nitrogen, available phosphorus and potassium were $0.08 \pm 0.01 \%$, $3.39 \pm 0.2 \mu \mathrm{g} \mathrm{g}^{-1}$ and $1.35 \pm 0.65 \mu \mathrm{g} \mathrm{g}^{-1}$ respectively. Moisture content of the soil was higher than that reported by Lamare and Singh (2017) ${ }^{37}$ who conducted study on changes in soil quality in a limestone mining area in East Jaintia Hills from the same state of Meghalaya, India. They reported soil moisture content which ranged from $5.55 \%$ to $6.86 \%$. The soil moisture content from our study site was higher because samples were collected on a rainy day. Soil moisture content from limestone mining sites is usually low due to presence of a mixture of granular, aggregated and blocky soil structure lowering the water holding capacity and also as a result of low organic matter ${ }^{37}$. Lamare and Singh (2017) also reported slightly alkaline nature of limestone soil ${ }^{37}$ and such soils are generally characterized by alkaline $\mathrm{pH}^{38}$. Soil organic carbon from our study site was also higher than that reported by Lamare and Singh (2017) who recorded $0.23 \%$ to $0.47 \%$ of soil organic carbon from intensively mined areas and the reason was probably our soil samples was a composite of samples collected from intensively mined and sparsely mined areas. Total soil nitrogen, though slightly higher than that reported by Lamare and 
Table 1. Biochemical and chemotaxonomic profile of actinobacterial isolates from the limestone mining site at Mawsmai, Meghalaya

\begin{tabular}{|c|c|c|c|c|c|c|c|}
\hline \multirow[b]{2}{*}{ Isolate } & \multirow[b]{2}{*}{$\begin{array}{c}\text { Casein } \\
\text { hydrolysis }\end{array}$} & \multicolumn{3}{|c|}{ Biochemical profile } & \multicolumn{2}{|c|}{ Chemotaxonomic profile } & \multirow[b]{2}{*}{$\begin{array}{l}\text { Identified } \\
\text { genera }\end{array}$} \\
\hline & & $\begin{array}{l}\text { Xanthine } \\
\text { hydrolysis }\end{array}$ & $\begin{array}{c}\text { Hypoxanthine } \\
\text { hydrolysis }\end{array}$ & $\begin{array}{l}\text { Tyrosine } \\
\text { hydrolysis }\end{array}$ & $\begin{array}{l}\text { Cell wall } \\
\text { DAP }\end{array}$ & $\begin{array}{c}\text { Whole cell } \\
\text { sugars }\end{array}$ & \\
\hline LD-01 & + & - & + & + & LL & Ara & Streptomyces \\
\hline LD-02 & - & + & + & + & $\mathrm{LL}$ & $\mathrm{Nd}$ & Streptomyces \\
\hline LD-03 & - & + & + & + & LL & $\mathrm{Nd}$ & Streptomyces \\
\hline LD-04 & + & + & + & + & LL & $\mathrm{Nd}$ & Streptomyces \\
\hline LD-05 & + & + & + & + & LL & $\mathrm{Nd}$ & Streptomyces \\
\hline LD-06 & + & + & + & + & LL & $\mathrm{Nd}$ & Streptomyces \\
\hline LD-07 & + & + & + & + & LL & $\mathrm{Nd}$ & Streptomyces \\
\hline LD-08 & + & + & + & + & LL & $\mathrm{Nd}$ & Streptomyces \\
\hline LD-09 & - & - & + & + & meso & Gal, Ara & Nocardia \\
\hline LD-10 & - & - & + & - & meso & Gal, Ara & Nocardia \\
\hline LD-11 & - & - & + & - & meso & Gal, Ara & Nocardia \\
\hline LD-12 & + & + & + & + & LL & Gal & Streptomyces \\
\hline LD-13 & - & - & + & + & meso & Gal, Ara & Nocardia \\
\hline LD-14 & + & + & + & + & LL & $\mathrm{Nd}$ & Streptomyces \\
\hline LD-15 & + & + & + & + & LL & $\mathrm{Nd}$ & Streptomyces \\
\hline LD-16 & + & - & + & - & meso & Gal, Ara & Nocardia \\
\hline LD-17 & - & - & - & + & meso & Gal, Ara & Nocardia \\
\hline LD-18 & - & + & + & + & LL & Gal & Streptomyces \\
\hline LD-19 & + & + & + & + & LL & Gal & Streptomyces \\
\hline LD-20 & - & - & - & - & meso & Gal, Xyl & Nocardia \\
\hline LD-21 & + & + & + & + & LL & $\mathrm{Nd}$ & Streptomyces \\
\hline LD-22 & + & + & + & + & LL & $\mathrm{Nd}$ & Streptomyces \\
\hline LD-23 & + & + & + & + & LL & Gal, Xyl & Streptomyces \\
\hline LD-24 & + & + & + & + & LL & $\mathrm{Nd}$ & Streptomyces \\
\hline LD-25 & + & + & + & + & LL & Xyl & Streptomyces \\
\hline LD-26 & + & + & + & + & LL & $\mathrm{Nd}$ & Streptomyces \\
\hline LD-27 & + & - & + & + & LL & Ara & Streptomyces \\
\hline LD-28 & + & + & + & + & LL & $\mathrm{Nd}$ & Streptomyces \\
\hline LD-29 & + & + & + & + & LL & $\mathrm{Nd}$ & Streptomyces \\
\hline LD-30 & - & + & + & + & LL & $\mathrm{Nd}$ & Streptomyces \\
\hline LD-31 & - & + & + & + & LL & $\mathrm{Nd}$ & Streptomyces \\
\hline LD-32 & + & + & + & + & LL & $\mathrm{Nd}$ & Streptomyces \\
\hline LD-33 & + & + & + & + & LL & $\mathrm{Nd}$ & Streptomyces \\
\hline LD-34 & + & + & + & - & $\mathrm{LL}$ & $\mathrm{Nd}$ & Streptomyces \\
\hline LD-35 & + & + & + & + & meso & $\mathrm{Nd}$ & Actinomadura \\
\hline LD-36 & - & - & + & - & LL & $\mathrm{Nd}$ & Streptomyces \\
\hline LD-37 & + & + & + & + & LL & $\mathrm{Nd}$ & Streptomyces \\
\hline LD-38 & + & + & + & + & LL & $\mathrm{Nd}$ & Streptomyces \\
\hline LD-39 & + & + & + & - & LL & $\mathrm{Nd}$ & Streptomyces \\
\hline LD-40 & + & + & + & + & LL & $\mathrm{Nd}$ & Streptomyces \\
\hline LD-41 & + & $+/-$ & - & + & LL & $\mathrm{Nd}$ & Streptomyces \\
\hline LD-42 & + & + & + & + & LL & $\mathrm{Nd}$ & Streptomyces \\
\hline LD-43 & + & + & + & + & LL & $\mathrm{Nd}$ & Streptomyces \\
\hline LD-44 & - & - & - & - & meso & Ara & Rhodococcus \\
\hline LD-45 & + & + & + & + & LL & $\mathrm{Nd}$ & Streptomyces \\
\hline LD-46 & - & - & + & + & meso & $\mathrm{Nd}$ & Nocardia \\
\hline LD-47 & - & - & + & + & meso & $\mathrm{Nd}$ & Nocardia \\
\hline
\end{tabular}

DAP, 2,6-diaminopimelic acid; LL and meso are two different isomers of DAP; Ara, Arabinose; Gal, Galactose; Xyl, Xylose; +, positive; -, negative; +/-, uncertain; Nd, Not detected 
Singh $(2017)^{37}$, was low due to loss of vegetation cover due to mining activities accompanied with loss of nitrogen-fixing microorganisms ${ }^{37}$. Available phosphorus and potassium were comparatively much lesser to that reported by Lamare and Singh $(2017)^{37}$. Other workers have also reported low levels of phosphorus and potassium from limestone mining $\operatorname{areas}^{39,40}$. Lamare and Singh (2017) however, reported no significant changes in phosphorus and potassium levels of limestonemined and unmined areas ${ }^{37}$. Generally, soil organic carbon, nitrogen, available phosphorus and potassium are relatively lower in concentration in limestone mining areas ${ }^{41}$.

Table 2. Detection of biosynthetic gene clusters (BGCs) in bioactive isolates by PCR

\begin{tabular}{lcllll}
\hline BGC & PCR & \multicolumn{3}{c}{ Bioactive isolates } \\
\cline { 3 - 6 } & $\begin{array}{c}\text { product } \\
\text { length } \\
(\mathrm{bp})\end{array}$ & LD-21 & LD-29 LD-34 LD-39 \\
& $1200-1400$ & - & + & + & + \\
\hline PKS-I & 600 & - & - & - & - \\
PKS-II & $700-800$ & + & + & + & + \\
NRPS & &
\end{tabular}

PKS-I, Type I polyketide synthase; PKS-II, Type II polyketide synthase; NRPS, Non-ribosomal peptide synthetase; +, PCR product detected; -, PCR product not detected.

\section{Isolation of actinobacteria}

Highest actinobacterial population number was recorded from un-pretreated and humic acid pretreated soil samples i.e. respectively $5.6 \pm 2.13 \times 10^{2}$ and $4.0 \pm 1.56 \times 10^{2} \mathrm{cfu}$ $\mathrm{g}^{-1}$ soil. Statistically insignificant difference was recorded in population number of these two methods at $p<0.05$ (Fig.1). The differences in population numbers between wet heat pretreated and humic acid pretreated samples were also statistically insignificant at $p<0.05$ (Fig.1). The three pretreatment methods were significantly better than the other pre-treatment methods. Minimum number of Actinobacteria was recovered using dry heating and phenol pretreatment methods. This may be because most actinobacteria are heat killed when samples are exposed to $100^{\circ} \mathrm{C}$ for a duration of one hour ${ }^{42}$ and phenol has been reported to reduce the growth of actinobacteria ${ }^{43}$. Among the selective media used, humic acid vitamin agar (HVA) and Streptomyces agar (SA) statistically gave the highest actinobacterial population number at $3.78 \pm 1.95 \times 10^{2}$ and $3.11 \pm 1.88 \times 10^{2}$

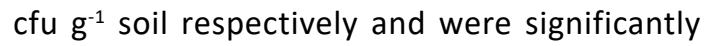
better than the other three media used at $p<0.05$ (Fig.1). Humic acid present in HVA serves the sole carbon and nitrogen sources and has been observed to activate spore germination in many actinobacterial species ${ }^{19}$. SA on the other hand is one of the routinely used media for selective

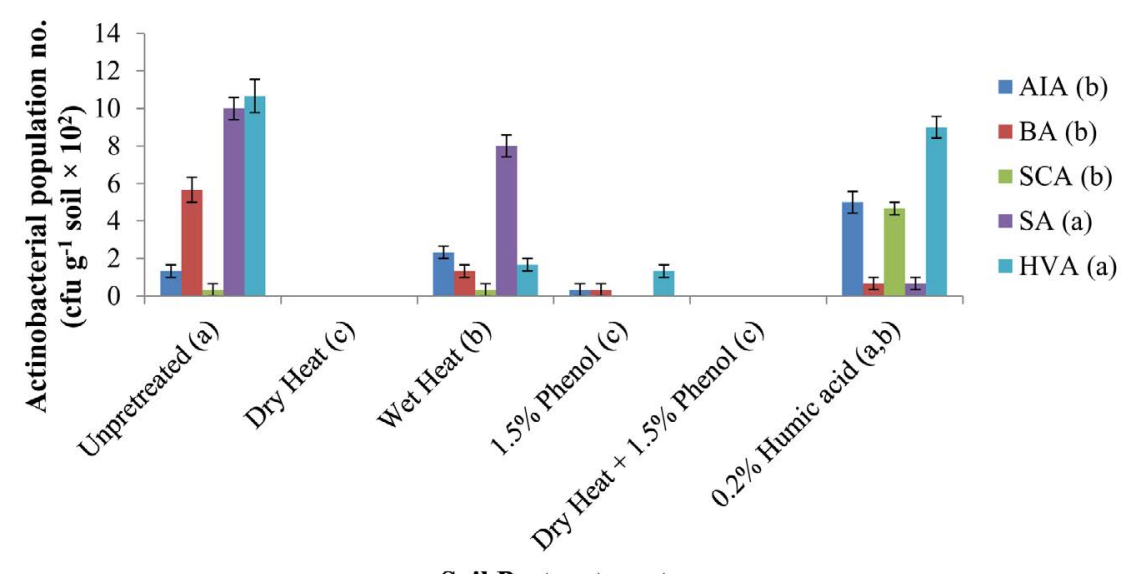

Soil Pretreatment

Fig.1. Recovery of actinobacteria from different pretreated soil samples on different selective media. (AIA, Actinomycete Isolation Agar; BA, Bennett's Agar; SCA, Starch Casein Agar; SA, Streptomyces Agar; HVA, Humic acid Vitamin Agar. Different lower case letters within parenthesis were significantly different among different pretreatments and among different selective media at $p<0.05$. Vertical bars represent standard error of mean.) 
isolation and maintenance of actinobacteria. The un-pretreated samples recorded highest actinobacterial population when inoculated on HVA $\left(10.67 \pm 0.88 \times 10^{2} \mathrm{cfu} \mathrm{g}^{-1}\right.$ soil) and SA media $\left(10.00 \pm 0.58 \times 10^{2} \mathrm{cfu} \mathrm{g}^{-1}\right.$ soil). The difference was, however, statistically insignificant at $\mathrm{p}<0.05$ (Fig.1). The actinobacterial population number recorded from humic acid pretreated sample inoculated on HVA medium $\left(9.00 \pm 0.58 \times 10^{2} \mathrm{cfu} \mathrm{g}^{-1}\right.$ soil) was also not significantly different from the unpretreated sample inoculated on SA medium $\left(10.00 \pm 0.58 \times 10^{2}\right.$ cfu $\mathrm{g}^{-1}$ soil).

\section{Diversity of actinobacteria}

On the basis of micromorphological characteristics, forty-seven isolates were identified as actinobacteria and all of them showed Gram- positive reaction. Based on biochemical and chemotaxonomic characteristics ${ }^{21,23}$, thirty-six isolates belonged to Streptomyces genera and the remaining eleven isolates were found to be non-streptomycetes, out of which nine were identified as Nocardia, one as Actinomadura and one as Rhodococcus (Table 1). From the cultivated isolates, it showed a dominance of Streptomyces genera which comprised $76 \%$ of the total number of isolates. Recent reports on actinobacteria from limestone niches have also shown Streptomyces to be the dominant genera $8,13,44,45$. A number of novel actinobacterial strains have also been reported from other limestone niches. Nimaichand et al. (2012) ${ }^{46}$ reported Streptomyces manipurensis sp. nov., a

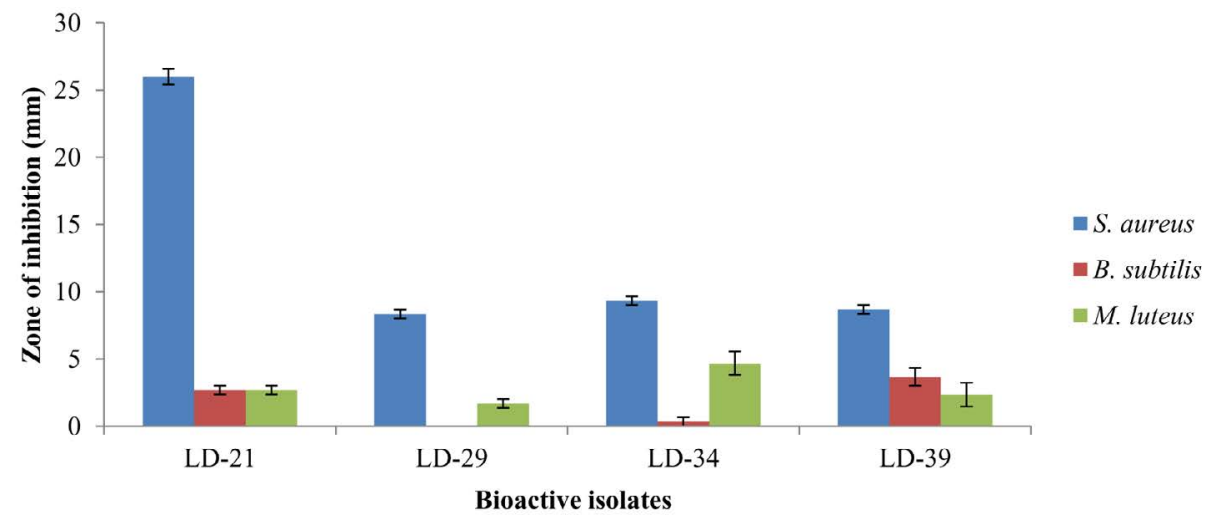

Fig.2. Antibacterial activity of culture filtrates prepared from the bioactive isolates by agar-well diffusion assay. (All the above bioactive isolates were identified as Streptomyces. S. aureus, Staphylococcus aureus MTCC 9886; B. subtilis, Bacillus subtilis MTCC 1305; M. luteus, Micrococcus luteus MTCC 1538. Vertical bars represent standard error of mean.)
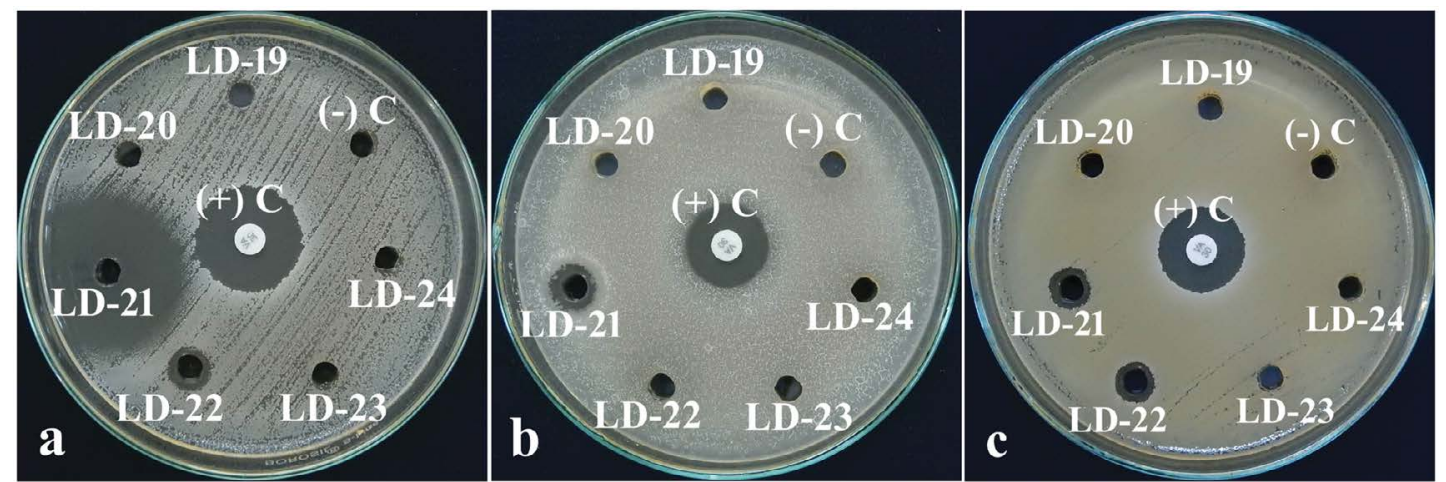

Fig. 3. Antibacterial activity of culture filtrate of bioactive isolate Streptomyces LD-21 and other isolates on a lawn of (a) Staphylococcus aureus, (b) Bacillus subtilis and (c) Micrococcus luteus.

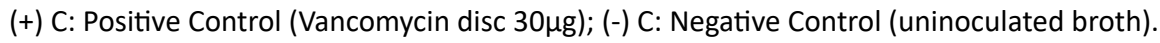


novel actinomycete, isolated from a limestone deposit site in Manipur, India. Li et al. (2014) ${ }^{47}$ reported Streptomyces canchipurensis sp. nov., isolated from a limestone environment at Hundung, Manipur, India. Cao et al. $(2015)^{48}$ reported
Lentzea guizhouensis sp. nov., a novel lithophilous actinobacterium isolated from limestone from the Karst area of Guizhou, China. Hezbri et al. (2015) $)^{49}$ reported Geodermatophilus sabuli sp. nov., a $\gamma$-radiation-resistant actinobacterium isolated

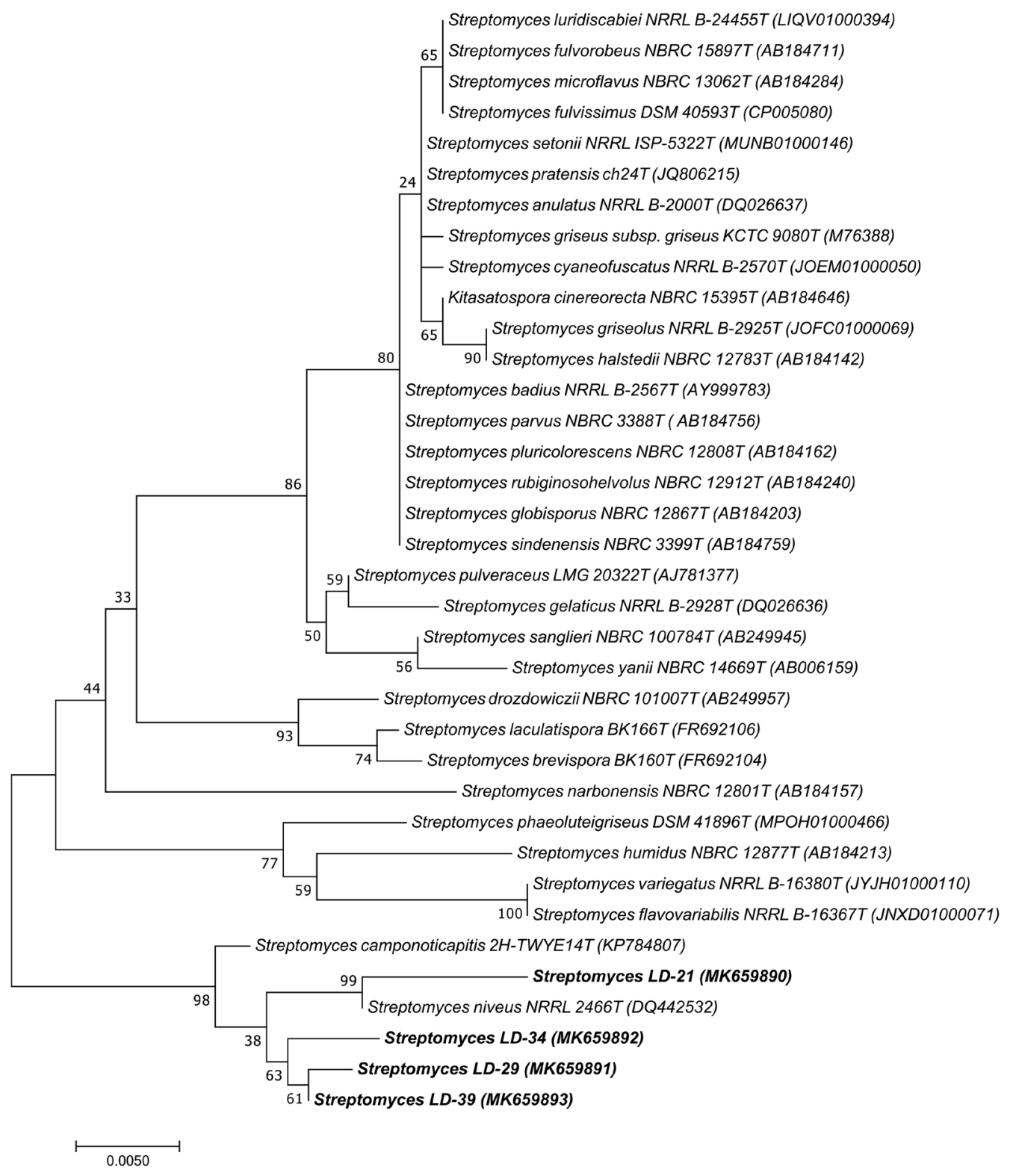

Fig.4. Maximum Likelihood Tree of the bioactive isolates (boldfaced) Streptomyces LD-21, Streptomyces LD-29, Streptomyces LD-34 and Streptomyces LD-39 along with related type strains based on 16S rDNA sequence.

(Alpha-numeric characters within parenthesis are GenBank accession numbers of the corresponding strains. The numbers at the nodes are bootstrap percentages based on 1000 replicates. Horizontal bar equals $0.5 \%$ sequence divergence.) 
from a limestone collected in the Sahara desert of Tunisia. Take et al. (2018) $)^{50}$ reported Streptomyces boninensis sp. nov., isolated from the soil of a limestone cave in the Ogasawara Islands of Japan. Dominance of Streptomyces from the cultivated isolates of this work signifies the adaptation of

Table 3. Minimum free energy (MFE) in $\mathrm{kcal} \mathrm{mol}^{-1}$ of the predicted $16 \mathrm{~S}$ rRNA secondary structures of the bioactive isolates along with thirty-two related type strains from EzBioCloud database. Five outgroups have also been included for comparison. The MFEs have been arranged in ascending order

\begin{tabular}{|c|c|}
\hline Strain & MFE (kcal mol$\left.{ }^{-1}\right)$ \\
\hline Micromonospora viridifaciens DSM $43909^{\top}\left(\mathrm{X}^{2} 2623\right)^{\$}$ & -553.1 \\
\hline Nonomuraea sp. GW $12687^{\top}$ (FN356742) & -552.1 \\
\hline Streptomyces niveus NRRL 2466 (DQ442532) & -542.7 \\
\hline Actinomadura darangshiensis DLS-70 ${ }^{\top}$ (FN646682) & -539.9 \\
\hline Streptomyces variegatus NRRL B-16380' (JYJH01000110) & -537.9 \\
\hline Streptomyces flavovariabilis NRRL B-16367 (JNXD01000071) & -537.9 \\
\hline Streptomyces pulveraceus LMG $20322^{\top}$ (AJ781377) & -536.3 \\
\hline Streptomyces gelaticus NRRL B-2928' (DQ026636) & -535.9 \\
\hline Streptomyces sanglieri NBRC $100784^{\top}$ (AB249945) & -535.1 \\
\hline Streptomyces narbonensis NBRC $12801^{\top}(\mathrm{AB} 184157)^{\mathrm{a}}$ & -534.7 \\
\hline Streptomyces LD-21 (MK659890) & -534.3 \\
\hline Kitasatospora cinereorecta NBRC $15395^{\top}$ (AB184646) & -532.9 \\
\hline Streptomyces badius NRRL B-2567 (AY999783) $^{\mathrm{b}}$ & -532.8 \\
\hline Streptomyces setonii NRRL ISP-5322 ${ }^{\top}$ (MUNB01000146) ${ }^{\mathrm{b}}$ & -532.8 \\
\hline Streptomyces parvus NBRC $3388^{\top}(\mathrm{AB} 184756)^{\mathrm{b}}$ & -532.8 \\
\hline Streptomyces camponoticapitis 2H-TWYE14 $4^{\top}\left(\right.$ KP784807) ${ }^{\mathrm{b}}$ & -532.8 \\
\hline Streptomyces pluricolorescens NBRC $12808^{\top}(A B 184162)^{b}$ & -532.8 \\
\hline Streptomyces rubiginosohelvolus NBRC $12912^{\top}(A B 184240)^{b}$ & -532.8 \\
\hline Streptomyces pratensis ch24 ${ }^{\top}(\mathrm{JQ} 806215)^{\mathrm{b}}$ & -532.8 \\
\hline Streptomyces anulatus NRRL B-2000 (DQ026637) ${ }^{\mathrm{b}}$ & -532.8 \\
\hline Streptomyces LD-39 (MK659893) & -532.3 \\
\hline Streptomyces drozdowiczii NBRC $101007^{\top}\left(\right.$ AB249957) ${ }^{\mathrm{b}}$ & -531.8 \\
\hline Streptomyces humidus NBRC $12877^{\top}$ (AB184213) & -531.7 \\
\hline Streptomyces phaeoluteigriseus DSM 41896' (MPOH01000466) & -530.8 \\
\hline Streptomyces LD-29 (MK659891) ${ }^{\mathrm{ct}}$ & -530.7 \\
\hline Streptomyces globisporus NBRC $12867^{\top}(\mathrm{AB} 184203)$ & -530.4 \\
\hline Streptomyces fulvissimus DSM 40593 (CP005080) & -530.4 \\
\hline Streptomyces microflavus NBRC $13062^{\top}$ (AB184284) & -530.4 \\
\hline Streptomyces luridiscabiei NRRL B-24455' (LIQV01000394) & -530.4 \\
\hline Streptomyces cyaneofuscatus NRRL B-2570' (JOEM01000050) & -530.2 \\
\hline Streptomyces griseolus NRRL B-2925' (JOFC01000069) & -530.2 \\
\hline Streptomyces halstedii NBRC $12783^{\top}$ (AB184142) & -530.2 \\
\hline Streptomyces sindenensis NBRC $3399^{\top}$ (AB184759) & -529.8 \\
\hline Streptomyces brevispora BK160' (FR692104) & -529.3 \\
\hline Streptomyces griseus subsp. griseus KCTC $9080^{\top}(\mathrm{M} 76388)^{d}$ & -528.5 \\
\hline Streptomyces LD-34 (MK659892) $)^{\mathrm{d} \#}$ & -528.5 \\
\hline Streptomyces laculatispora BK166'T (FR692106) & -528.3 \\
\hline Streptomyces fulvorobeus NBRC $15897^{\top}$ (AB184711) & -528 \\
\hline Mycolicibacterium fortuitum subsp. acetamidolyticum & -526.1 \\
\hline \multicolumn{2}{|l|}{ NCH E11620 (NR_104775) \$ } \\
\hline Nocardia brasiliensis ATCC $19296^{\top}(\mathrm{X} 80591)^{\$}$ & -524.8 \\
\hline Streptomyces yanii NBRC $14669^{\top}$ (AB006159) & -522.3 \\
\hline
\end{tabular}

a,b,c,d, Bioactive isolates along with their closest related type strains on the basis of MFEs; \#, Bioactive isolates from this work; $\$$, Outgroups 
this genus to thrive on a wide range of nutrients including the synthetic media used during isolation and the genus can also grow faster than the other slower-growing actinobacterial genera thereby establishing its micro niche much earlier than the others ${ }^{9}$.

\section{Antimicrobial activity}

Antimicrobial screening results from the agar well diffusion assay revealed that $19 \%$ of the isolates showed antibacterial activity against at least one of the bacterial strains tested. The screening results also showed stronger antibacterial activity against Gram-positive than Gram-negative bacteria. The isolates, however, did not show anti-candidal activity. Other recent reports on antimicrobial activity of actinobacteria from limestone niches also showed stronger anti-Gram-positive than anti-Gram-negative bacteria. Nimaichand et al. $(2015)^{8}$ reported on antimicrobial activity of actinobacteria from limestone deposit sites in Hundung, Manipur, India where eighteen actinobacterial isolates showed antibacterial activity against Gram-positive Bacillus subtilis and five isolates showed antibacterial activity against Gram-negative Escherichia coli. They however, also reported on isolates with anti-fungal activity including anti-candidal activity.
Maciejewska et al. (2016) $)^{9}$ also reported on antibacterial activity of moonmilk actinobacterial isolates from a limestone cave in Belgium where the isolates displayed stronger antibacterial activity against Gram-positive bacteria (94\% of the phylotypes) than Gram-negative bacteria (71\% of the phylotypes). They also reported on anti-fungal activity of the moonmilk isolates where $94 \%$ showed activity against a range of fungal strains including Candida albicans. Four isolates from this study viz. LD-21, LD-29, LD-34 and LD39 showed clear antibacterial activity against at least two Gram-positive bacteria (Fig.2). Isolate LD-21 showed the highest antibacterial activity against Staphylococcus aureus $(26 \pm 0.58 \mathrm{~mm})$. Antibacterial activity of culture filtrate of LD-21 is shown in Fig.3. The other three isolates viz. LD-29, LD-34 and LD-39 showed moderate antibacterial activity against $S$. aureus with zone of inhibition of $8.33 \pm 0.33,9.33 \pm 0.33$ and $8.67 \pm 0.33$ $\mathrm{mm}$ respectively. Isolates LD-21 and LD-39 showed low but clear antibacterial activity against Bacillus subtilis with zone of inhibition of $2.67 \pm 0.33$ and $3.67 \pm 0.67 \mathrm{~mm}$ respectively. All the above four isolates also showed low but clear antibacterial activity against Micrococcus luteus with zone of inhibition of $2.67 \pm 0.33,1.67 \pm 0.33,4.67 \pm 0.88$ and
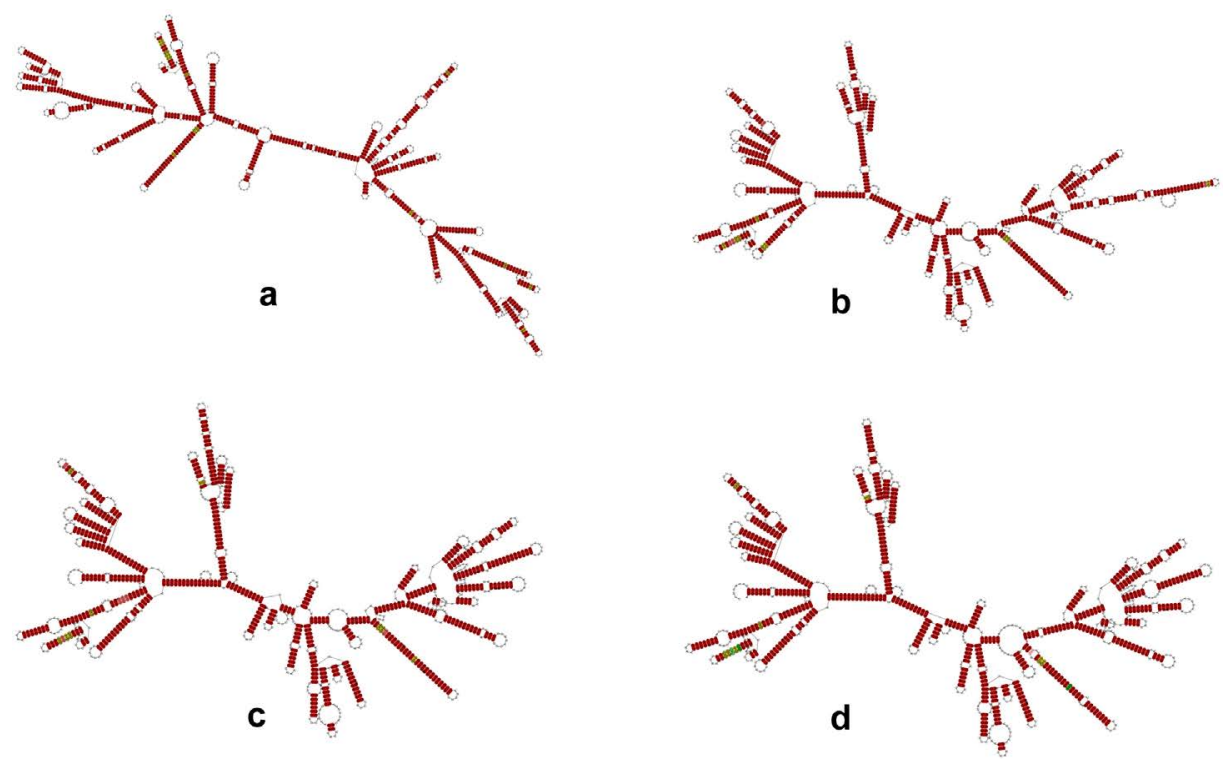

Fig.5. RNAalifold predicted consensus $16 \mathrm{~S}$ rRNA secondary structures of a Streptomyces LD-21, b Streptomyces LD-29, c Streptomyces LD-34 and d Streptomyces LD-39 with closely-related type strains based on minimum free energy. Regions shaded in brown denote highest degree of conservation with a single number of base pair type. 
$2.33 \pm 0.88 \mathrm{~mm}$ respectively. All the above four bioactive isolates also showed antibacterial activity against Gram-negative bacterium Pseudomonas aeruginosa but the zone of inhibition of their culture filtrates on the agar well diffusion assay were not as apparent as the positive control

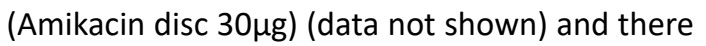
were no antibacterial activity against the other Gram-negative bacteria tested. The above four bioactive isolates also possessed at least one of the three biosynthetic gene clusters (BGCs) viz. PKS-I, PKS-II and NRPS (Table 2). Based on the antibacterial activity profile and BGCs, isolates LD-29, LD-34 and LD-39 seemed to have similar metabolic pathways and metabolite clusters. The antimicrobial screening results from this study recovered bioactive isolates with tendency of antimicrobial activity only towards Gram-positive bacteria and failed to recover isolates with broadspectrum antimicrobial activity. Yet this find is still significant considering the present era where more emphasis are being undertaken to develop narrower spectrum antimicrobial drugs (due to emergence of antimicrobial drug resistance) and recent advancements in rapid and more accurate diagnostic techniques ${ }^{5}$. It would therefore be interesting to test the above bioactive isolates against more Gram-positive indicator strains and multi-drug resistant clinical isolates. Optimization of the physico-chemical conditions for growth of the bioactive isolates for maximum production of bioactive metabolites ${ }^{51}$ is currently under way in the hope of finding novel bioactive metabolites.

\section{Identification of the bioactive isolates}

Based on morphological, biochemical and chemotaxonomic profiles (Table 1), all the four bioactive isolates were found to belong to Streptomyces genera. Phylogenetic analysis of their 16S rDNA sequences also confirmed to be Streptomyces. Isolate LD-21 was closest to Streptomyces niveus NRRL2466 ${ }^{\top}$ (DQ442532) with $99.47 \%$ sequence similarity and the other three isolates LD-29, LD-34 and LD-39 were closest to Streptomyces camponoticapitis $2 \mathrm{H}-\mathrm{TWYE}^{\mathrm{T}}{ }^{\mathrm{T}}$ (KP784807) with sequence similarity of $99.26 \%$, 99.41\% and $99.48 \%$ respectively. The generated phylogenetic tree of the bioactive isolates along with the related type strains is shown in Fig.4. GenBank accession numbers of the partial $16 \mathrm{~S}$ rDNA sequences of the bioactive isolates
LD-21, LD-29, LD-34 and LD-39 were assigned from MK659890 to MK659893 respectively. Therefore, the bioactive isolates are now identified as Streptomyces LD-21 (MK659890), Streptomyces LD-29 (MK659891), Streptomyces LD-34 (MK659892) and Streptomyces LD-39 (MK659893). The minimum free energy (MFE) in $\mathrm{kcal} \mathrm{mol}^{-1}$ of the predicted 16S rRNA secondary structures of the bioactive isolates also placed them under Streptomyces genera (Table 3). However, on the basis of MFEs, the Streptomyces species with the closest match have changed. The consensus 16S rRNA secondary structures of the bioactive isolates and their closely-related type strains (based on MFE) also showed high degree of conserved regions (Fig.5) confirming that the bioactive isolates belonged to Streptomyces genera. It was also noted that the consensus $16 \mathrm{~S}$ rRNA secondary structure of Streptomyces LD-21 looked different from the other three bioactive isolates Streptomyces LD-29, Streptomyces LD-34 and Streptomyces LD-39 while these three were similar in their consensus 16S rRNA secondary structures (Fig. 5) which agrees with the maximum likelihood tree (Fig. 4). Thus, it could be inferred that Streptomyces LD-29, Streptomyces LD-34 and Streptomyces LD-39 were phylogenetically closer to one another and they could even belong to the same strain and probably share very similar metabolic pathways and metabolite clusters as already mentioned which is evident from the antibacterial activity of their culture filtrates (Fig.2) and their BGC profiles (Table 2).

\section{CONCLUSION}

In present work, actinobacteria were isolated from a limestone mining site. The soil environment at the sample collection site was having minimal nutritional conditions (oligotrophic). Based on morphological, biochemical and chemotaxonomic characteristics, Streptomyces was found to be the dominant cultivable actinobacterium isolated from this environment. This, however, also suggests the use of more specific methods of isolation to recover the rarer genera of actinobacteria. Four bioactive isolates all identified as Streptomyces showed considerable antibacterial activity against Grampositive bacteria and they were also found to harbor at least one of the three biosynthetic 
gene clusters viz. PKS-I, PKS-II and NRPS which are related to synthesis of bioactive metabolites. More work is needed to assess their activity over a range of the Gram-positive bacterium including multi-drug resistant strains. Optimization of bioactive metabolites production by the bioactive isolates is under way. This under-explored niche from Meghalaya is important for mining of actinobacteria for obtaining novel bioactive metabolites that might have applications in various fields.

\section{ACKNOWLEDGMENTS}

The authors sincerely thank the Department of Botany, Gauhati University, Guwahati, Assam for providing facilities under SAP (DRS-I) and FIST to complete this work.

\section{CONFLICTS OF INTEREST}

The authors declare that there is no conflict of interest.

\section{AUTHORS' CONTRIBUTION}

All authors have made substantial, direct and intellectual contribution to the work and approved it for publication.

\section{FUNDING}

None

\section{DATA AVAILABILITY}

All datasets generated or analyzed during this study are included in the research work.

\section{ETHICS STATEMENT}

This article does not contain any studies with human participants or animals performed by any of the authors.

\section{REFERENCES}

1. Goodfellow M. Phylum XXVI. Actinobacteria phyl. nov p.33. In Goodfellow M, Kampfer P, Busse H-J, Trujillo ME, Suzuki K-i, Ludwig W, Whitman WB (eds.), Bergey's Manual of Systematic Bacteriology, Volume Five: The Actinobacteria, $2^{\text {nd }}$ Ed. Springer, 2012.

2. Genilloud O. Actinomycetes: Still a source of novel antibiotics. Nat. Prod. Rep., 2017; 34(10): 1203-1232.

3. Berdy J. Bioavtive microbial metabolites - A personal view. J. Antibiot. (Tokyo), 2005; 58(1): 1-26.

4. Wright G.D. Something old, something new: revisiting natural products in antibiotic drug discovery. Can. J. Microbiol., 2014; 60(3): 147-154.
5. Fischbach M.A., Walsh C.T. Antibiotics for emerging pathogens. Science, 2009; 325(5944): 1089-1093.

6. Lawrence J. Drug discovery returns to the wild. Pharm. J., 2015; 294(7849): online. doi:10.1211/ PJ.2015.20067820

7. Mohite O.S., Weber T., Kim H.U., Lee S.Y. Genomescale metabolic reconstruction of actinomycetes for antibiotics production. Biotechnol. J., 2019; 14(1): 1800377 (1-9).

8. Nimaichand S., Devi A.M., Tamreihao K., Ningthoujam D.S., Li W.J. Actinobacterial diversity in limestone deposit sites in Hundung, Manipur (India) and their antimicrobial activities. Front Microbiol., 2015; 6: 413.

9. Maciejewska M., Adam D., Martinet L., Naome A., Calusinska M., Delfosse P., Carnol M., Barton H.A., Hayette M.P., Smargiasso N., De Pauw E., Hanikenne M., Baurain D., Rigali S. A phenotypic and genotypic analysis of the antimicrobial potential of cultivable Streptomyces isolated from cave moonmilk deposits. Front Microbiol., 2016; 7: 1455.

10. Adam D., Maciejewska M., Naome A., Martinet L., Coppieters W., Karim L., Baurain D., Rigali S. Isolation, characterization and antibacterial activity of hard-toculture actinobacteria from cave moonmilk deposits. Antibiotics, 2018; 7(2): 28.

11. Belyagoubi L., Belyagoubi-Benhammou N., Jurado V., Dupont J., Lacoste S., Djebbah F., Ounadjela F.Z., Benaissa S., Habi S., Abdelouahid D.E., Saiz-Jimenez C. Antimicrobial activities of culturable microorganisms (Actinomycetes and fungi) isolated from Chaabe Cave, Algeria. Int. J. Speleol., 2018; 47(2): 189-199.

12. Covington B.C., Spraggins J.M., Ynigez-Gutierrez A.E., Hylton Z.B., Bachmann B.O. Response of secondary metabolism of hypogean actinobacterial genera to chemical and biological stimuli. Appl. Environ. Microbiol., 2018; 84(19): e01125-18.

13. Hamedi J., Kafshnouchi M., Ranjbaran M. A Study on actinobacterial diversity of Hampoeil cave and screening of their biological activities. Saudi J Biol Sci, 2018; In Press. doi:10.1016/j.sjbs.2018.10.010

14. Yasir M. Analysis of bacterial communities and characterization of antimicrobial strains from cave microbiota. Brazilian J. Microbiol., 2018; 49(2): 248257.

15. Myers N., Mittermeier R.A., Mittermeier C.G., da Fonseca G.A.B., Kent J. Biodiversity hotspots for conservation priorities. Nature, 2000; 403(6772): 853-858.

16. Allen S.E., Grimshaw H.M., Parkinson J.A., Quarmby C. Chemical Analysis of Ecological Materials. Blackwell Scientific, Oxford, 1974.

17. Anderson J.M., Ingram J.S.I. Tropical Soil Biology and Fertility: A Handbook of Methods. 2nd Ed. C.A.B International, Wallingford, 1993.

18. Jackson M.L. Soil Chemical Analysis. Prentice Hall of India Pvt. Ltd., New Delhi, 1973.

19. Hayakawa M., Nonomura H. Humic acid-vitamin agar, a new medium for the selective isolation of soil actinomycetes. J. Ferment. Technol., 1987; 65(5): 501509.

20. Cross T. Growth and examination of actinomycetes: Some guidelines, pp. 605-609. In Holt JG, Sneath PH, 
Krieg NR (eds.), Bergey's Manual of Determinative Bacteriology, $9^{\text {th }}$ Ed. Williams \& Wilkins, Baltimore, 1994.

21. Berd D. Laboratory identification of clinically important aerobic actinomycetes. Appl Microbiol., 1973; 25(4): 665-681.

22. Hasegawa T., Takizawa M., Tanida S. A rapid analysis for chemical grouping of aerobic actinomycetes. J. Gen. Appl. Microbiol., 1983; 29(4): 319-322.

23. Staneck J.L., Roberts G.D. Simplified approach to identification of aerobic actinomycetes by thin-layer chromatography. Appl. Environ. Microbiol., 1974; 28(2): 226-231.

24. Chen X., Jiang Y., Li Q., Han L., Jiang C. Molecular Phylogenetic Identification of Actinobacteria, 2016, pp. 141-174. In Dhanasekaran D., Jiang Y. (eds.), Actinobacteria: Basics and Biotechnological Applications. ExLi4EvA. doi:10. 5772/62029

25. Monciardini P., Sosio M., Cavaletti L., Chiocchini C., Stefano D. New PCR primers for the selective amplication of 16S rDNA from different groups of actinomycetes. FEMS Microbiol. Ecol., 2002; 42: 419429.

26. Yoon S.H., Ha S.M., Kwon S., Lim J., Kim Y., Seo H., Chun J. Introducing EzBioCloud: A taxonomically united database of 16S rRNA gene sequences and wholegenome assemblies. Int. J. Syst. Evol. Microbiol., 2017; 67(5): 1613-1617.

27. Kumar S., Stecher G., Tamura K. MEGA7: Molecular Evolutionary Genetics Analysis Version 7.0 for Bigger Datasets. Mol. Biol. Evol., 2016; 33(7): 1870-1874.

28. Tamura K. Estimation of the number of nucleotide substitutions when there are strong transitiontransversion and $\mathrm{G}+\mathrm{C}$-content biases. Mol. Biol. Evol., 1992; 9(4): 678-687.

29. Felsenstein J. Confidence limits on phylogenies: An approach using the bootstrap. Evolution (N.Y.), 1985; 39: 783-791.

30. Ghosh A., Sutradhar S., Baishya D. Delineating thermophilic xylanase from Bacillus licheniformis DM5 towards its potential application in xylooligosaccharides production. World J. Microbiol. Biotechnol., 2019; 35(2): 34.

31. Gruber A.R., Lorenz R., Bernhart S.H., Neubock R., Hofacker I.L. The Vienna RNA websuite. Nucleic Acids Res., 2008; 36: W70-W74.

32. Bernhart S.H., Hofacker I.L., Will S., Gruber A.R., Stadler P.F. RNAalifold: Improved consensus structure prediction for RNA alignments. BMC Bioinformatics, 2008; 9: 474.

33. Otoguro M., Hayakawa M., Yamazaki T., limura Y. An integrated method for the enrichment and selective isolation of Actinokineospora spp. in soil and plant litter. J. Appl. Microbiol., 2001; 91(1): 118-130.

34. Holder I.A., Boyce S.T. Agar well diffusion assay testing of bacterial susceptibility to various antimicrobials in concentrations non-toxic for human cells in culture. Burns, 1994; 20(5): 426-429.

35. Ayuso-Sacido A., Genilloud O. New PCR primers for the screening of NRPS and PKS-I systems in actinomycetes: Detection and distribution of these biosynthetic gene sequences in major taxonomic groups. Microb. Ecol.,
2005; 49(1): 10-24.

36. Shankar U., Tripathi R.S., Pandey H.N. Structure and seasonal dynamics of humid tropical grasslands in Meghalaya, India. J. Veg. Sci., 1991; 2(5): 711-714.

37. Lamare R.E., Singh O.P. Changes in soil quality in limestone mining area of Meghalaya, India. Nat Environ. Pollut. Technol., 2017; 16(2): 545-550.

38. Misra A., Tyler G. Influence of soil moisture on soil solution chemistry and concentrations of minerals in the Calcicoles Phleum phleoides and Veronica spicata grown on a limestone soil. Ann. Bot., 1999; 84(3): 401-410.

39. Cohen-Fernandez A.C., Naeth M.A. Erosion control blankets, organic amendments and site variability influenced the initial plant community at a limestone quarry in the Canadian Rocky Mountains. Biogeosciences, 2013; 10(7): 5243-5253.

40. Sarwanto D., Prayitno C.H. The diversity and productivity of indigenous forage in former limestone mining quarry in karst mountain of Southern Gombong, Central Java Indonesia. Anim. Prod., 2015; 17(2): 6975.

41. Hanief S.M., Thakur S.D., Gupta B. Vegetal profile of natural plant succession and artificially re-vegetated limestone mines of Himachal Pradesh, India. J. Trop. For., 2007; 23: 128-135.

42. Seong C.N., Choi J.H., Baik K. An improved selective isolation of rare actinomycetes from forest soil. J. Microbiol., 2001; 39(1): 17-23.

43. Hayakawa M., Nonomura H. A new method for the intensive isolation of actinomycetes from soil. Actinomycetologica, 1989; 3(2): 95-104.

44. Cao C., Jiang J., Sun H., Huang Y., Tao F., Lian B. Carbonate mineral formation under the influence of limestone-colonizing actinobacteria: Morphology and polymorphism. Front Microbiol, 2016; 7: 366.

45. Fang B-Z, Salam N., Han M-X, Jiao J-Y, Cheng J., Wei D-Q, Xiao M., Li W-J. Insights on the effects of heat pretreatment, $\mathrm{pH}$, and calcium salts on isolation of rare actinobacteria from karstic caves. Front Microbiol., 2017; 8: 1535.

46. Nimaichand S., Zhu W.Y., Yang L.L., Ming H., Nie G.X., Tang S.K., Ningthoujam D.S., Li W.J. Streptomyces manipurensis sp. nov., a novel actinomycete isolated from a limestone deposit site in Manipur, India. Antonie Van Leeuwenhoek, 2012; 102(1): 133-139.

47. Li W-J, Nimaichand S., Jiang Z., Liu M-J, Khieu T-N, Kim C-J, Hozzein W.N., Park D-J, Wadaan M.A.M., Ningthoujam D.S. Streptomyces canchipurensis sp. nov., isolated from a limestone habitat. Antonie Van Leeuwenhoek, 2014; 106: 1119-1126.

48. Cao C.L., Zhou X.Q., Qin S., Tao F.X., Jiang J.H., Lian B. Lentzea guizhouensis sp. nov., a novel lithophilous actinobacterium isolated from limestone from the Karst area, Guizhou, China. Antonie Van Leeuwenhoek, 2015; 108(6): 1365-1372.

49. Hezbri K., Ghodhbane-Gtari F., Montero-Calasanz M.C., Sghaier H., Rohde M., Schumann P., Klenk H.P., Gtari M. Geodermatophilus sabuli sp. nov., a $\gamma$-radiation-resistant actinobacterium isolated from desert limestone. Int. J. Syst. Evol. Microbiol., 2015; 65(10): 3365-3372. 
50. Take A., Inahashi Y., Omura S., Takahashi Y., Matsumoto A. Streptomyces boninensis sp. nov., isolated from soil from a limestone cave in the Ogasawara Islands. Int. J. Syst. Evol. Microbiol., 2018; 68: 1795-1799.

51. Deka D., Jha D.K. Optimization of culture parameters for improved production of bioactive metabolite by endophytic Geosmithia pallida (KU693285) isolated from Brucea mollis Wall ex. Kurz, an endangered medicinal plant. J. Pure Appl. Microbiol., 2018; 12(3): 1205-1213. 